\title{
EFEKTIFITAS PROGRESSIVE MUSCLE RELAXATION (PMR) TERHADAP TEKANAN DARAH PADA PENDERITA HIPERTENSI DI DESA BANJARSARI SERANG BANTEN
}

\author{
M. Arifki Zainaro ${ }^{1 *}$, Sekardhyta Ayuning Tias², Rahma Elliya ${ }^{3}$ \\ DOI: https://doi.org/10.33024/jkpm.v4i4.2843 \\ ${ }^{1,3}$ Dosen Keperawatan Universitas Malahayati \\ ${ }^{2}$ Mahasiswa Program Studi Ilmu Keperawatan Universitas Malahayati \\ Disubmit: 11 Juni 2020 Diterima: 01 Agustus 2021 Diterbitkan: 02 Agustus 2021 \\ Email Korespondensi: m.arifkiz@yahoo.com
}

\begin{abstract}
ABSTRAK
Hipertensi merupakan suatu keadaan meningkatnya tekanan darah sistolik lebih dari sama dengan $140 \mathrm{mmHg}$ dan diastolik lebih dari sama dengan $90 \mathrm{mmHg}$. Beberapa penanganan dalam hipertensi yaitu penanganan non farmakologis yaitu teknik relaksasi napas dalam, pijat refleksi kaki, hipnoterapi dan relaksasi otot progresif (Progressive Muscle Relaxation), beberapa keistimewaan dari teknik relaksasi otot profresif ini yaitu menurunkan ketegangan otot, sakit kepala, menurunkan tekanan darah sistolik dan diastolic. Tujuan penelitian, untuk mendapatkan pengalaman dan kompetensi lebih dalam pemberian asuhan keperawatan komprehensif pemberian terapi Progressive Muscle Relaxation (PMR) terhadap penurunan tekanan darah. Adapun kegiatan yang dilakukan berupa penyuluhan menggunakan leaflet dan demonstrasi terapi Progressive Muscle Relaxation (PMR). Terdapat penurunan tekanan darah setelah dilakukan terapi Progressive Muscle Relaxation (PMR) pada penderita hipertensi. Dengan demikian, terapi Progressive Muscle Relaxation (PMR) sangat efektif dalam menurunkan tekanan darah.
\end{abstract}

Kata Kunci: Progressive Muscle Relaxation (PMR), Hipertensi, Tekanan Darah

\section{ABSTRACT}

Hypertension is a state of increased systolic blood pressure of more than $140 \mathrm{mmHg}$ and diastolic more than equal to $90 \mathrm{mmHg}$. Some treatments in hypertension are non-pharmacological treatments namely deep breathing relaxation techniques, foot reflexology massage, hypnotherapy and progressive muscle relaxation (Progressive Muscle Relaxation). diastolic. The goal of the study was to gain more experience and competence in the provision of comprehensive nursing care in the provision of Progressive Muscle Relaxation (PMR) therapy for reducing blood pressure. The activities carried out in the form of counseling using leaflets and demonstrations of Progressive Muscle Relaxation (PMR) therapy. There is a decrease in blood pressure after Progressive Muscle Relaxation (PMR) therapy in patients with hypertension. Thus, Progressive Muscle Relaxation (PMR) therapy is very effective in lowering blood pressure.

Keywords: Progressive Muscle Relaxation (PMR), Hypertension, Blood Pressure 


\section{PENDAHULUAN}

Berdasarkan WHO (2012), negara yang memiliki penghasilan tinggi memiliki prevalensi hipertensi lebih kecil dari negara berkembang atau negara yang memiliki penghasilan yang rendah. Dari 927 juta penderita hipertensi di dunia, sebanyak 333 juta penderita berada di negara maju dan 639 juta penderita sisanya terdapat di negara berkembang. Hipertensi merupakan faktor penting yang memengaruhi hampir satu miliar orang di seluruh dunia dan menyebabkan sekitar 7,1 juta kematian per tahun pada usia dewasa.

Kementerian Kesehatan (2018) menyatakan bahwa di Indonesia terjadi peningkatan prevalensi hipertensi dari 25,8\% tahun 2013 menjadi 34,1\% pada tahun 2018. Di Indonesia penyakit hipertensi dan komplikasinya merupakan peringkat kelima dari sepuluh besar penyebab kematian tertinggi terhitung dari 41.590 kematian dari Januari sampai Desember 2018. Kenaikan prevalensi ini berhubungan dengan pola hidup, antara lain merokok, konsumsi minuman beralkohol, aktifitas fisik, serta konsumsi buah dan sayur (Riskesdas, 2018).

Hipertensi merupakan suatu keadaan meningkatnya tekanan darah sistolik lebih dari sama dengan $140 \mathrm{mmHg}$ dan diastolik lebih dari sama dengan $90 \mathrm{mmHg}$. Hipertensi seringkali tidak menimbulkan gejala, sementara tekanan darah yang terus-menerus tinggi dalam jangka waktu lama dapat menimbulkan komplikasi. Oleh karena itu, hipertensi perlu dideteksi dini yaitu dengan pemeriksaan tekanan darah secara berkala.

Beberapa penanganan dalam hipertensi yaitu penanganan farmakologis dan non farmakologis yaitu teknik relaksasi napas dalam, relaksasi aroma terapi mawar, terapi mandi uap, pijat refleksi kaki, hipnoterapi dan relaksasi otot progresif (Progressive Muscle Relaxation), beberapa keistimewaan dari teknik relaksasi otot profresif ini yaitu menurunkan ketegangan otot, kecemasan nyeri leher, sakit kepala, sakit punggung, frekuensi jantung, frekuensi pernapasan laju metabolic, menurunkan denyut nadi, menurunkan tekanan darah sistolik dan diastolic serta mengurangi stress pada lansia, menurunkan kecemasan dan depresi dengan meningkatkan control diri (Akhriansyah, 2018).

Hasil penelitian awal didapatkan Kota Serang merupakan prevalensi Hipertensi tertinggi diantara Kabupaten atau Kota yang ada di Banten yaitu 31\%, sedangkan urutan yang kedua adalah Kabupaten Tanggerang dengan jumlah 28\%, Kota Tanggerang Selatan 22,2\%, kemudian Pandeglang 16,5\% dan yang paling rendah adalah Kota Cilegon 11,9\% (Profil Dinkes Banten, 2019).

Berdasarkan latar belakang tersebut, penulis tertarik untuk melakukan studi kasus "Asuhan Keperawatan Komprehensif Pada Klien Hipertensi Dengan Masalah Peningkatan Tekanan Darah Dengan Progressive Muscle Relaxation (PMR) Di Desa Banjarsari Serang Banten Tahun 2020". 


\section{MASALAH}

Alasan kami memilih tempat penyuluhan kesehatan tentang hipertensi dan pemberian terapi Progressive Muscle Relaxation (PMR) di Desa Banjarsari Serang Banten ialah karena keluarga dilingkungan ini memiliki masalah kesehatan Hipertensi yang tinggi, dimana tujuan umum dalam kegiatan ini diharapkan pemberian terapi Progressive Muscle Relaxation (PMR) dapat menurunkan tekanan darah pada klien dengan hipertensi, dan tujuan khusus dalam kegiatan yaitu asuhan keperawatan, telaah jurnal untuk menentukan intervensi, evaluasi hasil aplikasi intervensi, perbandingan hasil intervensi pemberian terapi Progressive Muscle Relaxation (PMR).

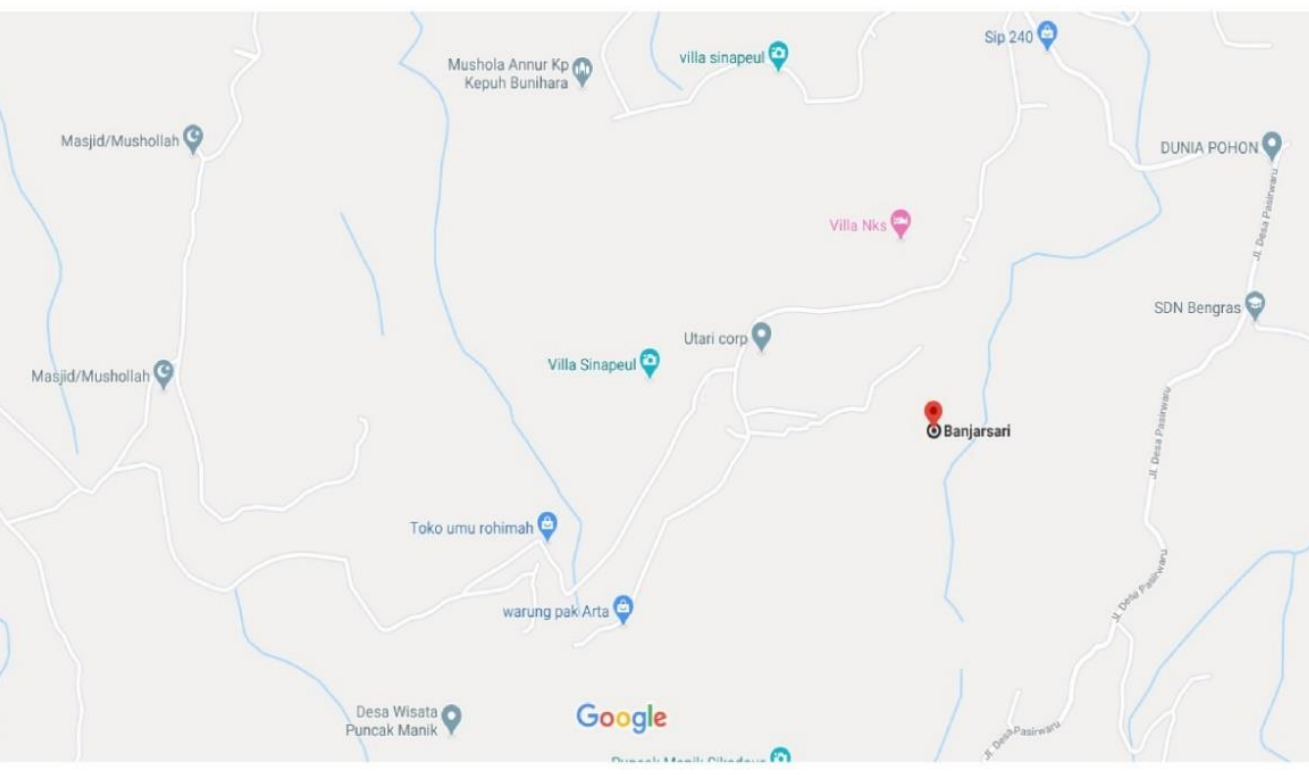

Gambar 2.1 Lokasi penyuluhan dan demonstrasi

\section{METODE}

1. Tujuan Persiapan

Tahap persiapan dari kegiatan adalah pembuatan pre planning, persiapan penyajian leaflet dan demonstrasi, tempat dan alat-alat lainnya disiapkan oleh peneliti. Pada tanggal 02 mei 2020 dilakukan penyuluhan, pengecekan tekanan darah, dan demonstrasi terapi Progressive Muscle Relaxation (PMR).

2. Tahap Pelaksanaan

Kegiatan ini dengan pemberitahuan kepada klien, dan dilanjutkan penyuluuhan, pengecekan tekanan darah, dan demonstrasi terapi Progressive Muscle Relaxation (PMR).

3. Evaluasi

a. Struktur

Peserta hadir 3 orang yaitu perempuan. Setting tempat sudah sesuai dengan rencana dan perlengkapan yang dilakukan untuk penyuluhan sudah tersedia dan sudah digunakan sebagaimana mestinya. Peran peneliti sebagai moderator, 
notulen, observer, dan juga fasilitator. Penggunaan bahasa yang dipraktekkan sudah komunikatif dalam penyampaian, klien dapat memahami dan dapat mempraktekkan kembali yang di demonstrasikan.

b. Proses

Pelaksanaan kegiatan dilaksanakan pada tanggal 02 Mei 2020 dilakukan selama 7 hari. Sesuai dengan jadwal yang sudah ditentukan.

c. Hasil

1. Klien dapat memahami dan mengerti tentang pengertian terapi Progressive Muscle Relaxation (PMR).

2. Klien dapat memahami dan mengerti tentang tujuan dilakukannya terapi Progressive Muscle Relaxation (PMR).

3. Klien dapat memahami dan mengerti tentang manfaat dan teknik terapi Progressive Muscle Relaxation (PMR).

4. Klien dapat memahami dan mengerti tentang langkah-langkah terapi Progressive Muscle Relaxation (PMR).

\section{HASIL DAN PEMBAHASAN}

a. Hasil

Metode pelaksanaan pemberian terapi Progressive Muscle Relaxation (PMR)dilaksanakan pada tanggal 02 Mei 2020 s/d 08 Mei 2020. Penelitian dilakukan selama 7 hari, setelah dilakukan pemberian terapi selama 7 hari didapatkan tekanan darah klien menurun. Berikut pelaksanaan penyuluhan, pengecekan tekanan darah dan pemberian terapi Progressive Muscle Relaxation (PMR):

Tabel 4.1

Tekanan Darah Sebelum dan Sesudah Pemberian terapi Progressive Muscle Relaxation (PMR)

\begin{tabular}{|c|c|c|c|c|c|c|c|c|}
\hline \multirow{3}{*}{$\begin{array}{l}\text { Nama } \\
\text { Pasien }\end{array}$} & \multicolumn{8}{|c|}{ Hasil Pemeriksaan } \\
\hline & \multirow{2}{*}{$\begin{array}{c}\text { Tekanan } \\
\text { Darah saat } \\
\text { pengkajian }\end{array}$} & \multicolumn{7}{|c|}{ Sesudah Tindakan Hari Ke } \\
\hline & & 1 & 2 & 3 & 4 & 5 & 6 & 7 \\
\hline Ny.E & $\begin{array}{c}160 / 100 \\
\mathrm{mmHg}\end{array}$ & $\begin{array}{c}160 / 100 \\
\mathrm{mmHg}\end{array}$ & $\begin{array}{l}160 / 90 \\
\mathrm{mmHg}\end{array}$ & $\begin{array}{c}150 / 100 \\
\mathrm{mmHg}\end{array}$ & $\begin{array}{l}150 / 90 \\
\mathrm{mmHg}\end{array}$ & $\begin{array}{l}150 / 80 \\
\mathrm{mmHg}\end{array}$ & $\begin{array}{l}140 / 90 \\
\mathrm{mmHg}\end{array}$ & $\begin{array}{l}140 / 80 \\
\mathrm{mmHg}\end{array}$ \\
\hline Ny.R & $\begin{array}{c}150 / 100 \\
\mathrm{mmHg}\end{array}$ & $\begin{array}{c}150 / 100 \\
\mathrm{mmHg}\end{array}$ & $\begin{array}{l}150 / 90 \\
\mathrm{mmHg}\end{array}$ & $\begin{array}{l}150 / 90 \\
\mathrm{mmHg}\end{array}$ & $\begin{array}{l}140 / 90 \\
\mathrm{mmHg}\end{array}$ & $\begin{array}{l}140 / 70 \\
\mathrm{mmHg}\end{array}$ & $\begin{array}{l}130 / 100 \\
\mathrm{mmHg}\end{array}$ & $\begin{array}{l}130 / 80 \\
\mathrm{mmHg}\end{array}$ \\
\hline
\end{tabular}

\section{b. Pembahasan}

Berdasarkan Tabel 4.1 menunjukkan hasil evaluasi pada klien, dimana klien mengalami penurunan tekanan darah setelah dilakukan pemberian terapi Progressive Muscle Relaxation (PMR) selama 7 hari berturut-turut. Pada tabel dapat dilihat evaluasi hari terakhir pemeriksaan tekanan darah terjadi penurunan antara klien $1 \mathrm{Ny}$. E, dan klien $2 \mathrm{Ny}$. R, diperoleh data pada klien $1 \mathrm{Ny}$. E tekanan darah sebelum diberikan asuhan keperawatan yaitu $160 / 100 \mathrm{mmHg}$. Pada klien $2 \mathrm{Ny}$. R tekanan darah sebelum diberikan asuhan keperawatan yaitu 150/100 mmHg. 
Analisis peneliti didapatkan adanya perbandingan hasil dari terapi Progressive Muscle Relaxation terhadap penrunan tekanan darah pada Ny.E dan Ny.R. Pada Ny.E didapatkan hasil penurunaan tekanan darah yang kurang signifikan, hal ini dikarenakan adanya kebiasaan Ny.E yang sulit untuk dihilangkan yaitu kebiasaan Ny.E merokok dan minum kopi. Sedangkan pada Ny.R didapatkan hasil yang signifikan, hal ini bisa terjadi dikarenakan kepatuhan klien dalam menerapkan terapi komplementer Progressive Muscle Relaxation dan kepatuhan pasien pada pantangan atau larangan yang harus dihindarkan bagi penderita hiptertensi.

Hasil penelitian ini sesuai dengan penelitian sebelumnya yang dilakukan oleh Akhriyansyah. M, dengan judul Pengaruh Progressive Muscle Relaxation (PMR) Terhadap Penurunan Tekanan Darah Pada Lansia Hipertensi Di Panti Social Tresna Werdha Palembang. Menggunakan metode Quasi Experimental Pre-Post test with Control Grup dengan jumlah sampel 30 orang, hasil uji kesetaraan mendapatkan hasil $p$ value $>0,05$. Hal ini menunjukkan tidak ada perbedaan bermakna rata-rata tekanan darah lansia pada kelompok intervensi dan kelompok kontrol. Hasil penelitian menunjukkan bahwa lansia yang mendapat intervensi kondisi sistolik menurun secara bermakna ( $p$ value $<0,05$ ) dari 159,3 mmHg menjadi 130,6 mmHg. Sedangkan pada kelompok control tekanan darah sistolik tidak mengalami penurunan yang signifikan ( $p$ value $>0,05$ ) dari 160,6 mmHg menjadi $155,3 \mathrm{mmHg}$.

Hipertensi merupakan suatu keadaan meningkatnya tekanan darah sistolik lebih dari sama dengan $140 \mathrm{mmHg}$ dan diastolik lebih dari sama dengan $90 \mathrm{mmHg}$. Hipertensi dapat diklasifikasikan menjadi dua jenis yaitu hipertensi primer atau esensial yang penyebabnya tidak diketahui dan hipertensi sekunder yang dapat disebabkan oleh penyakit ginjal, penyakit endokrin, penyakit jantung, dan gangguan anak ginjal. Hipertensi seringkali tidak menimbulkan gejala, sementara tekanan darah yang terus-menerus tinggi dalam jangka waktu lama dapat menimbulkan komplikasi. Oleh karena itu, hipertensi perlu dideteksi dini yaitu dengan pemeriksaan tekanan darah secara berkala.

Beberapa penanganan dalam hipertensi yaitu penanganan farmakologis dan non farmakologis yaitu teknik relaksasi napas dalam, relaksasi aroma terapi mawar, terapi mandi uap, pijat refleksi kaki, hipnoterapi dan relaksasi otot progresif (Progressive Muscle Relaxation), beberapa keistimewaan dari teknik relaksasi otot profresif ini yaitu menurunkan ketegangan otot, kecemasan nyeri leher, sakit kepala, sakit punggung, frekuensi jantung, frekuensi pernapasan laju metabolic, menurunkan denyut nadi, menurunkan tekanan darah sistolik dan diastolic serta mengurangi stress pada lansia, menurunkan kecemasan dan depresi dengan meningkatkan control diri (Akhriansyah, 2018).

Factor resiko yang dapat meningkatkan terjadinya hipertensi adalah pola makan yaitu asupan natrium. Asupan natrium yang tinggi berhubungan erat dengan kejadian hipertensi. Selain dari asupan natrium yang tinggi yaitu kebiasaan merokok, dan kebiasaan minum kopi juga diketahui sebagai penyebab terjadinya hipertensi.

Konsumsi natrium yang berlebih akan meningkatkan volume cairan ekstraseluler. Dari meningkatnya volume cairan ekstraseluler tersebut menyebabkan meningkatnya volume darah yang berdampak pada timbulnya hipertensi 
Zat - zat kimia beracun dalam rokok dapat mengakibatkan tekanan darah tinggi atau hipertensi. Salah satu zat beracun tersebut nikotin, dmana nikotin dapat meningkatkan adrenalin yang membuat jantung berdebar lebih cepat dan bekerja lebih keras, frekuensi denyut jantung meningkat dan kontraksi jantung meningkat sehingga menimbulkan tekanan darah meningkat (Retnaningsih. D. Dkk, 2016).

Kopi yang masuk ke dalam tubuh akan didistribusikan keseluruh tubuh oleh aliran darah dari traktus gastro intestinal dalam waktu 5-15 menit. Absrorbsi kafein dalam saluran pencernaan mencapai kadar $99 \%$ kemudian akan mencapai puncak di aliran darah dalam waktu 45-60 menit. Kafein merupakan kandungan terbesar dalam kopi yang memiliki efek terhadap tekanan darah terutama pada penderita hipertensi. Peningkatan tekanan darah ini terjadi melalui mekanisme biologi antara lain kafein mengikat reseptor adenosine, mengaktifasi system saraf simpatik dengan meningkatkan konsentrasi cathecolamines dalam plasma, dan menstimulasi kelenjar adrenalin serta meningkatkan produksi kortisol. Hal ini berdampak pada vasokontriksi dan meningkatkan total resistensi perifer, yang akan menyebabkan tekanan darah naik (Kurniawaty. E \& Insan. A, 2016).
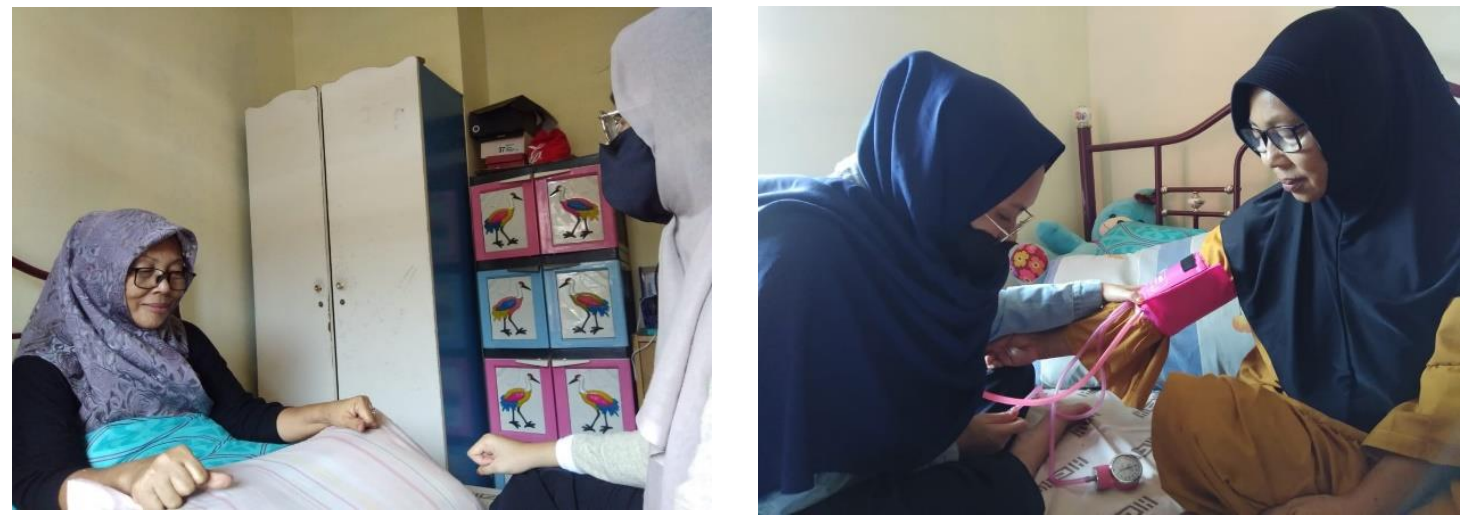

Gambar 4.1 pelaksanaan penyuluhan, pengecekan tekanan darah, dan pemberian terapi Progressive Muscle Relaxation (PMR)
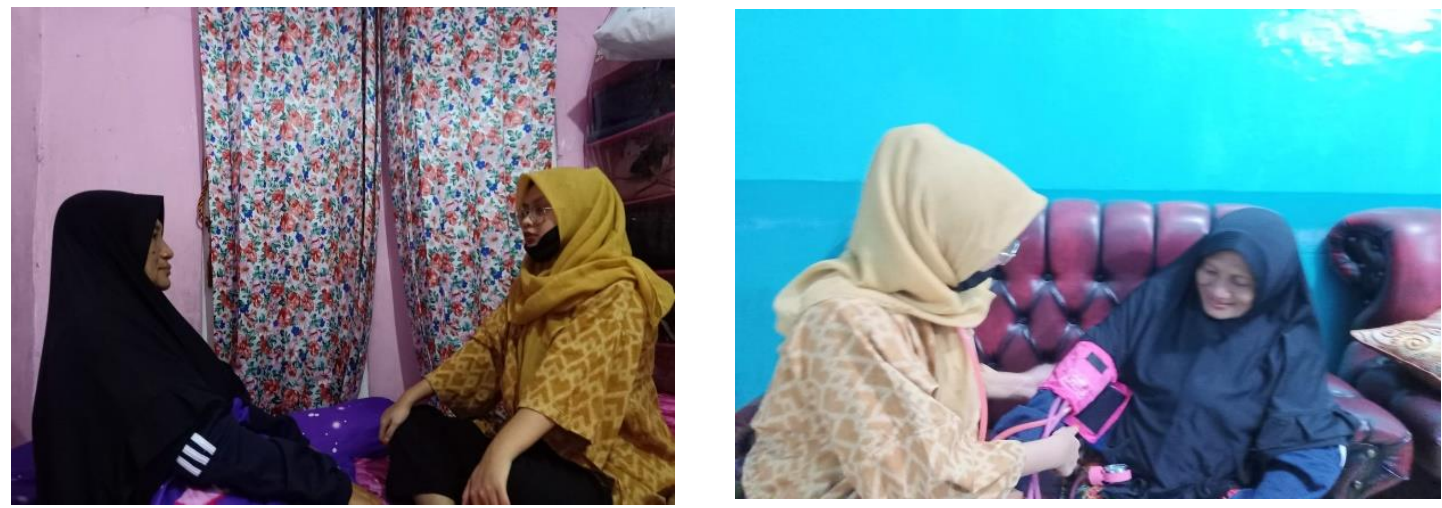

Gambar 4.1 pelaksanaan penyuluhan, pengecekan tekanan darah, dan pemberian terapi Progressive Muscle Relaxation (PMR) 


\section{KESIMPULAN}

Saat dilakukan pengkajian pada klien ditemukan data yang sesuai dengan tinjauan teori untuk masalah Hipertensi pada klien. Berdasarkan data yang diperoleh, peneliti mendapatkan diagnosa keperawatan yang harus ditangani yang akan dijadikan suatu masalah. Pada intervensi keperawatan yang dilakukan pada klien yaitu sesuai dengan diagnosa keperawatan dan dilakukan pemberian madu. Implementasi Keperawatan yang dilakukan berdasarkan pada intervensi yang telah direncanakan.

Terapi non farmakologi Progressive Muscle Relaxation (PMR) terbukti dapat menurunkan tekanan darah pada penderita hipertensi, dengan dilakukan terapi selama 7 hari. Terdapat penurunan tekanan darah setelah dilakukan terapi Progressive Muscle Relaxation (PMR) pada penderita hipertensi. Dengan demikian, terapi Progressive Muscle Relaxation (PMR) sangat efektif dalam menurunkan tekanan darah. Hal ini dikarenakan adanya beberapa keistimewaan dari teknik relaksasi otot profresif ini yaitu menurunkan ketegangan otot, kecemasan nyeri leher, sakit kepala, sakit punggung, frekuensi jantung, frekuensi pernapasan laju metabolic, menurunkan denyut nadi, menurunkan tekanan darah sistolik dan diastolic serta mengurangi stress pada lansia, menurunkan kecemasan dan depresi dengan meningkatkan control diri (Akhriansyah, 2018).

\section{DAFTAR PUSTKA}

Mubarrak, dkk. (2012). Ilmu Keperawatan Komunitas 2; Konsep Dan Aplikasi. Jakarta: Salemba Medika

Friedman, Marilyn M dkk. (2010). Buku Ajar : Keperawatan Keluarga Riset, Teori \&Praktik. Jakarta : EGC

Muttaqin. (2009). Pengantar Asuhan Keperawatan Klien Dengan Gangguan Sistem Kardiovaskular. Jakarta: Salemba Medika

Nurarif \& Kusuma. (2015). Asuhan Keperawatan Berdasarkan Diagnosa Medis \& NANDA NIC-NOC. Jogjakarta : MediAction

Harmoko, (2012). Asuhan Keperawatan Keluarga. Yogyakarta: Pustaka Pelajar

Udjianti, W. J. (2010). Keperawatan Kardiovaskuler. Jakarta: Salemba Medika

Ismudiati, Lily. (2004). Buku Ajar Kardiologi. Jakarta : FKUI

Muttaqin, A. Editor Nurachmach, E. (2009). Asuhan Keperawatan Klien Gangguan Sistem Kardiovaskuler. Jakarta: Salemba Medika..

Nanda. (2014). Diagnosis Keperawatan Definisi dan Klasifikasi 2012-2014. Jakarta : EGC

Patricia A. Potter, Anne G. Perry. Editor dr. Dripa Sjabana. (2009). Fundamentals of Nursing Fundamental Keperawatan Buku 1 Edisi 7. Jakarta : Salemba Medika

Kemenkes RI. (2014). Info Data Dan Informasi Kesehatan Indonesia Tahun 2013. Jakarta : Kemenkes RI.

Wijaya, Andra S \&Putri, Yesi M. (2013). Keperawatan Medikal Bedah. Yogyakarta: Nuha Medika

Brunner \& Suddarth. (2015). Keperawatan Medikal Bedah Edisi 12. Jakarta : ECG.

Smeltzer, Suzanne C, Brenda G bare. (2005). Buku Ajar Keperawatan Medikal Bedah. Brunner \& Suddarth Edisi 8 Vol 2 alih bahasa 
Muttaqin A. (2014). Pengantar Asuhan Keperawatan Klien Dengan Gangguan Sistem Kardiovaskular. Jakarta: Salemba Medika

Nurarif \& Kusuma. (2013). Asuhan Keperawatan berdasarkan Diagnosa Medis \& NANDA NIC-NOC. Jogjakarta : MediAction

Dinas Kesehatan Provinsi Banten Tahun 2019. (2019). Profil Kesehatan Provinsi Banten. Banten.

Akhriansyah. M. (2018). Pengaruh Progressive Muscle Relaxation (PMR) terhadap Penurunan Tekanan Darah Pada Lansia Hipertensi Di Panti Sosial Tresna Werdha Palembang Provinsi Sumatera Selatan Tahun 2018. Diakses Tanggal 13 April 2020. Pukul 11.57 Wib.

Rusnoto. Dkk. (2016). Pengaruh Terapi Progressive Muscle Relaxation Terhadap Penurunan Tekanan Darah Pada Prolanis. Diakses Tanggal 13 April 2020. Pukul 11.59 Wib.

Rahmawati. Dkk. (2018). Efektifitas Progressive Muscle Relaxation (PMR) Terhadap Penurunan Tekanan Darah Pada Penderita Hipertensi. Diakses Tanggal 19 April 2020. Pukul 08.52 Wib.

Setyaningrum. Dkk. (2018). Efektifitas Progressive Muscle Relaxation Dengan Zikir Terhadap Penurunan Tekanan Darah dan Penurunan Tingkat Stres Pada Penderita Hipertensi. Diakses Tanggal 19 April 2020. Pukul 22.02 Wib.

Sulistyani. Dkk. (2015). Relaksasi Otot Progresif Terhadap Tekanan Darah Pada Penderita Hipertensi Esensial. Diakses Tanggal 19 April 2020. Pukul 15.06 Wib.

Fitrianti. Dkk. (2018). Pemberian Relaksasi Otot Progresif Pada Lansia Dengan Hipertensi Esensial Di Kota Jambi. Diakses Tanggal 15 April 2020. Pukul 10.57 Wib. 